\title{
Problems in Sino - Foreign Cooperation in Running Higher Education and the Countermeasures
}

\author{
Yang Chunli \\ Weinan Normal University, Weinan, Shaanxi, 714000
}

Keywords: higher education; Sino-foreign cooperation in running schools; problems and countermeasures

\begin{abstract}
With the deepening of China's reform and opening up, the reform in the field of education has also promoted the rapid development of Sino-foreign cooperation in running schools. Especially in the field of higher education, both the type and scale of cooperative education have been further expanded and the mode of running schools has become more diversified. The level of running schools has also been continuously improved. However, in the actual development, because China's foreign cooperation in running schools is still in the exploratory stage, some problems inevitably exist. The paper summarizes the advantages of Sino-foreign cooperation in running higher education in China. It analyzes many problems existing in the actual situation and proposes specific solutions to provide reference for the development of Chinese-foreign cooperation in higher education.
\end{abstract}

\section{The advantages of Sino-foreign cooperative education in higher education}

Compared with traditional institutions of higher learning, the advantages of Sino-foreign cooperative education are mainly reflected in the following aspects [1-2]:

\subsection{Lay a solid foundation for Sino-foreign cooperation in running schools}

The internationalization of higher education in our country is no longer an empty slogan. Its diversified and popular development has proved to be the best evidence. Sino-foreign cooperative education is an important part of China's education and it is the main task of Sino-foreign cooperative education. It is not only a necessary measure to promote the development of education in our country, but also it is an important way for rejuvenating the nation through science and technology. As a result, it strengthens the nation by technology.

\subsection{Learn from foreign advanced educational experience}

Relatively speaking, the higher education in our country is still in the stage of growth. However, the higher education in developed countries in Europe and the United States is relatively mature. Cooperation with these countries with developed educational technologies can create a more favorable external environment for higher education in our country.

\subsection{Provide high-quality production and research platform for Sino-foreign cooperation in running schools.}

In higher education, the cooperative education of production, study and research in the process of human cultivation is of great significance. Sino-foreign cooperation in running schools not only enables students to understand the advanced theoretical knowledge and technology in the world. However, the most colleges and universities have good cooperation foundation with high-tech enterprises. They can provide students with a good platform for production and research to help them improve their theoretical level and practical skills.

\section{Problems in Sino-foreign cooperation in running schools}

In the field of higher education in our country, Sino-foreign cooperation in running schools is 
still in its infancy. Therefore, there are still many problems [3-4]:

\subsection{Low level of overall schooling}

However, the objective of this policy is far from being achieved. In particular, undergraduate colleges and universities have generally low levels. Some are not famous abroad and their quality is low. The educational institutions have higher enthusiasm for Sino-foreign cooperative education at this level of specialization, but this enthusiasm is only for the pursuit of economic interests. Therefore, the level of cooperation in running schools is generally not high. At present, many Chinese-foreign collaborators in many undergraduate colleges are mostly overseas famous Universities. Both the academic reputation and the quality of the courses cannot be guaranteed. Domestic and foreign truly first-class universities and first-class professional cooperation opportunities are still rare. There are many economic and management disciplines and few science and engineering courses. Sino-foreign cooperation in running schools lacks the characteristics of our school when setting majors. It cannot achieve the goal of optimizing the educational resources of our school. The gap between teachers and library materials is also large. And a scientific teaching system has not been formed. Teaching in the aspect of management, the overseas credit system is copied. It cannot give full play to the advantages of Sino-foreign cooperation in running schools. In addition, although our country explicitly demands that Sino-foreign cooperative education not be for profit, some schools still neglect the purpose of education and emphasize that the organization of profit-making. It will not only affect the development of students, but also it causes bad social conditions impact [3].

\subsection{Extreme quality students increase the difficulty of Sino-foreign cooperation in running schools}

Compared with the domestic colleges and universities, the Chinese-foreign cooperation in running schools has some particularities. The characteristics of students recruited are different. On the one hand, there are bi-polar characteristics in student quality. Many institutions of Sino-foreign cooperative education run unplanned admissions. These students usually have low college entrance scores, failing to meet the national admission score. And only a small part of students have a high level of basic knowledge. Most students do not dominate. On the other hand, the family backgrounds of the students are rather special. Most of the families are richer and have a stronger sense of superiority, which gives them a strong sense of self-awareness. In addition, students from Chinese-foreign cooperative education should not only receive professional study, but also they work hard in learning languages and adapting to two different teaching systems. Therefore, the learning pressure is rather high while the low quality of students will directly affect the learning effect. Over time, it will affect the reputation of running a school and further increase the difficulty of Sino-foreign cooperation in running schools [4].

\subsection{Teachers limited ability to meet the needs of running schools}

The teacher resources of Sino-foreign cooperative education include foreign teachers and Chinese teachers. Among them, foreign teachers still have many problems in introducing teachers. There are the following problems, such as the imperfect introduction mechanism, the lack of effective supervision, the too-simple teacher recruitment procedure and the inability to guarantee the teaching level of foreign teacher. And the large mobility of foreign teachers makes them poorly aware of the conditions of schools and students. Many foreign teachers cannot teach in Chinese and students' understanding of English is very limited. Therefore, the quality of teaching cannot be guaranteed. In addition, the teaching materials of Sino-foreign cooperative colleges and universities mostly use the original English textbooks, multi-application of foreign language teaching in professional courses, highlighting bilingualism. This case requires teachers not only have a solid professional knowledge, but also have excellent oral English expression ability. However, there are few teachers in existing cooperative colleges and universities that possess both professional skills and good foreign language fundamentals. Therefore, it is necessary to train and introduce a group of teachers who possess both professional skills and certain foreign language skills [5]. 


\subsection{School operations are too commercial}

The contradiction between marketability and public welfare has led to the growing color of the commercial operation of Chinese-foreign cooperative schools in our country. Although our country's requirement for Sino-foreign cooperative education is "a public welfare undertaking", its fundamental goal is to cultivate talents. However, most countries that cooperate with our country regard. It can increase their income. Driven by economic interests and the market, some third-rate foreign universities will come to China to seize China's education market. Some domestic universities have weaker comprehensive strengths. However, due to the limited demand in the domestic market, most schools must attract more students by improper means to improve their educational competitiveness, which eventually leads to a decline in the quality of Sino-foreign cooperative education. It is not conducive to its long-term development [6].

\section{To promote China's higher education strategy of Sino-foreign cooperation in running schools}

In view of the existing problems of Chinese-foreign cooperation in running higher education in China, it is suggested that the following aspects should be taken to improve the quality of Chinese-foreign cooperation in running higher education in China [7-8]:

\subsection{To improve the quality of students}

The main goal of Sino-foreign cooperative education in higher education is to cultivate a composite and applied talent with an international perspective. It innovative spirit and practical ability with high training objectives, special curricula and differences in teaching methods, all of which raise the quality of students request. However, in reality, it is unrealistic to rely on the method of raising the threshold to improve the quality of students. Therefore, we should do well in the school education of students. Strengthen the reinforcement of English foundation and tutoring students to better adapt to bilingual teaching. A good job in ideological and political work of students can help them establish a correct world outlook, outlook on life, values, cultivate a strong learning ability, good practical skills of high quality student. Of course, the actual enrollment process cannot blindly pursue the number of students. It is necessary to appropriately improve admission standards to ensure the quality of students.

\subsection{To improve the level of Chinese teachers, the use of MOOC to carry out part of the teaching}

Therefore, it is necessary to improve the level of teachers in the country and provide them with more opportunities for further studies. For example, teachers who have strong knowledge of foreign languages can send them abroad for further studies through the exchange program. It can make learn more teaching methods and management experience. After returning home it can be regarded as the backbone of bilingual education. In addition, MOOC can be also used to solve the problem of lack of foreign teachers. The so-called MOOC is "Massive open online course". Through MOOC, teachers and students can use the Internet to carry out teaching activities without regional restrictions and help students integrate into the foreign teaching atmosphere in advance. In MOOC learning process, students may be supervised by regularly submitting study reports. It corrects homework assignments and other assessment methods to supervise their high-quality completion of online courses. In addition, we must further improve the teaching evaluation system of cooperative education. Teaching evaluation system is an effective teaching quality management tool, which reflects the function of good guidance, motivation and audit. Sino-foreign cooperative colleges and universities should combine their own actual conditions with the students to establish and improve the teaching evaluation system. Teaching quality can make a scientific assessment to identify problems, analyze problems, solve problems, and constantly improve the quality of education and teaching of teachers. 


\subsection{Stick to the public welfare of Sino-foreign cooperation in running schools}

Higher education is a public welfare undertaking that cannot be left for commercialization in order to co-operate in education. Therefore, it is necessary to uphold the public welfare nature of Sino-foreign cooperative education. It actively seeks foreign educational institutions aiming at educational assistance and strengthening cooperation with such organizations. Cooperation in running schools, it establishes a good role model. In the management of running a school, if there is a conflict between public welfare and marketability in schools, it is necessary to correct the target of running a school and ensure a steady source of running money for running schools. It takes into account the economic benefits of running investors and the public welfare of running schools. Chinese-foreign cooperative education institutions can sign talent cultivation plans and sponsorship agreements with some large-scale enterprises. Enterprises provide scholarships to schools to encourage students with outstanding achievements related to the company's business majors. They can not only mobilize students' enthusiasm for learning kind of make up for the high cost of cooperation in running schools. Cooperative enterprises can also provide more internship opportunities for students and improving students' practical ability by means of batch internship, centralized internship, experience internship and other means. For some outstanding students, cooperative enterprises can provide more Employment opportunities. It can alleviate the pressure of employment of students, but also it can provide enterprises with outstanding personnel. It can guarantee the commonweal of cooperation in running schools. The cooperative schools can also employ relevant trainee instructors from enterprises to conduct internship and graduation design of students jointly around collaborative research projects.

\section{Conclusions}

In short, our institutions of higher learning in the development process strengthen cooperation with foreign universities. It carries out cooperation in running some of the models, which greatly broadened the horizons of our colleges and universities. It enriches the teaching resources and effectively improves our college personnel quality. It also improves the overall level of running colleges and universities in our country. Of course, although Sino-foreign cooperation in running schools has achieved some success in a short time, there are still many problems. The problems mainly contain low grade, poor student quality, weak teachers and serious commercialization in Sino-foreign cooperative education. Institutions of higher learning for Sino-foreign cooperation in running schools of higher education should strive to learn from the excellent experience of foreign countries. It should find out the appropriate Of Sino-foreign cooperation in running schools. Optimizing the original project can make it to the professional and characteristic direction.

\section{Acknowledgements}

This work was supported by Weinan Teachers College International Cooperation in Education Science Project: Study on the Coordinated Development of Chinese-Foreign Cooperation in Running Schools and Regional Economy in Local Colleges and Universities (17GJHZ33).

\section{References}

[1] Li Shengbing, Wang Zhiqiang. Study on the Status Quo and Countermeasures of Sino-foreign Cooperation in Running Schools in Guangdong Universities [J]. Higher Education Exploration, 2015 (2): 66-68

[2] Tan Meiqiong. Prospects and development of Sino-foreign cooperative education [J]. Science and Technology Monthly, 2016 (11): 109- 110

[3] LIN Wei, TAO Lin.Analysis on the Problems, Principles and Countermeasures of Current Sino-foreign Cooperation in Running Schools [J]. Journal of Nanjing Medical University (Social Science Edition), 2016 (3): 251- 253 
[4] Xu Zhiwei. Analysis of management mode of Sino-foreign cooperative education in colleges and universities [J]. Journal of Shenyang Normal University (Social Science Edition), 2016 (5): 1213

[5] Li Yanhui. Overview of Sino-foreign cooperative education in higher vocational education [J]. Jincheng Polytechnic, 2010 (3): 5-7

[6] Sun Weidong, Song Yanqing. Study on the path of higher vocational education cooperation Based on the empirical analysis of Jiangsu Province [J]. Vocational Education Forum, 2014 (2): 43-46

[7] Wang Jinxia. Analysis of sustainable development of Sino-foreign cooperation in running schools in higher vocational colleges [J]. Journal of Shandong Agricultural Administrators College, 2013 (4): 172-174

[8] Zhang Jinbo. Problems and Countermeasures of Sino-foreign Cooperation in Higher Vocational Education [J]. Business Teaching, 2012 (3): 62-66 